\title{
EUROPEAN COMMISSION
}

EXTERNAL RELATIONS DIRECTORATE GENERAL

DIRECTORATE ASIA (EXCEPT JAPAN AND KOREA)

Unit H.4 - Pakistan, Afghanistan, Bangladesh, Sri Lanka, Maldives

\section{COUNTRY STRATEGY PAPER (CSP)}

\section{AFGHANISTAN}

2003-2006

Including National Indicative Programme 2003-2004

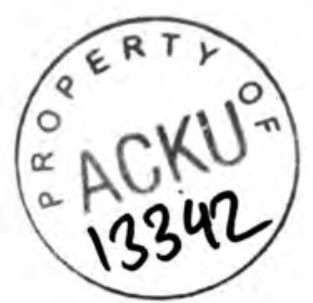




\section{TABLE OF CONTENTS}

EXECUTIVE SUMMARY

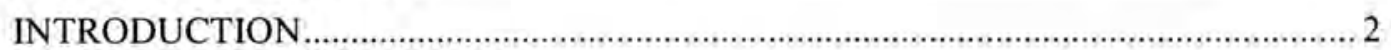

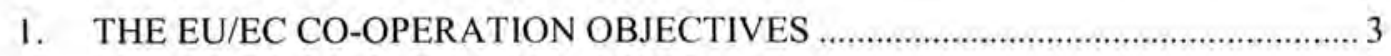

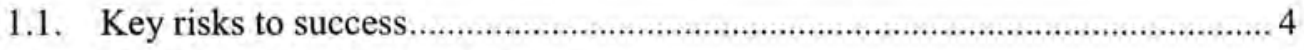

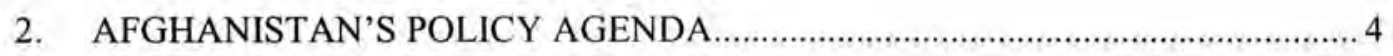

2.1. National Development Framework ........................................................... 5

2.2. The National Development and Recurrent Budget: Setting

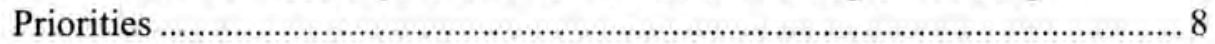

2.3. Implementation Mechanisms …………...................................................... 9

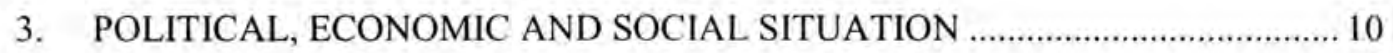

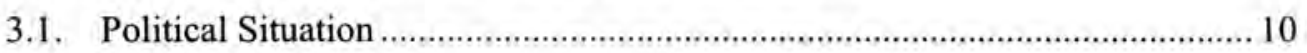

3.2. The Social and Economic Situation ........................................................ 12

3.3. The Emerging Economic Policy Framework …............................................ 14

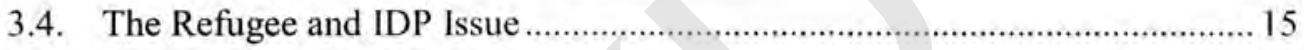

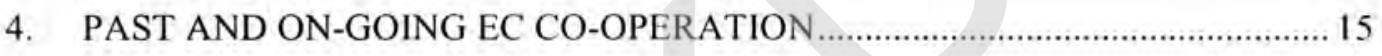

4.1. EC Co-operation Pre-September 11 ........................................................... 15

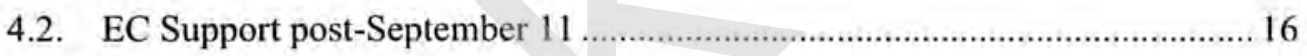

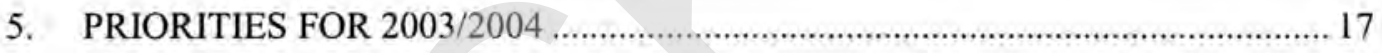

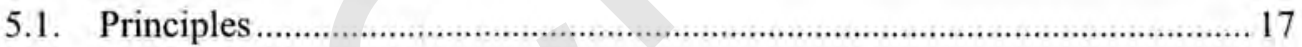

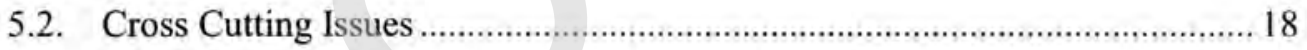

5.3. Managing the Interface of Humanitarian and Reconstruction

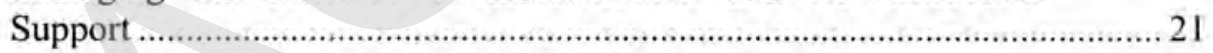

5.4. Coherence and Complementarity with Other Donors .................................. 21

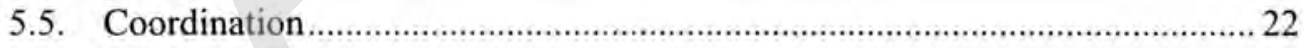

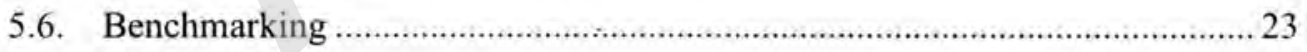

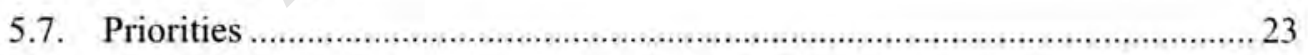

5.7.1. Pillar 1 - Human Capital and Social Protection .............................. 24

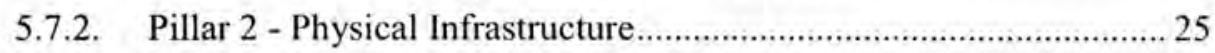

5.7.3. Pillar 3 - Trade and Investment, Public Administration and Security. .26

Annexes:

1. The Bonn Agreement

2. Conclusions from July 2002 General Affairs Council

3. Co-chairs Summary of Tokyo Pledging Conference January 2002 


\section{Key terms and abbreviations}

Afghanistan Assistance Coordination Authority - AACA

Afghanistan Reconstruction Steering Group - ARSG

Afghanistan Reconstruction Trust Fund - ARTF

Afghanistan Transitional Authority - ATA

Afghan Support Group - ASG

Asian Development Bank - ADB

Consultative Group - CG

Development Budget - DB

European Commission Humanitarian Office - ECHO

General Affairs Council - GAC

Implementation Group - IG

Internally Displaced Persons - IDPs

International Monetary Fund - IMF

Islamic Development Bank - IsDB

Local Consultative Group - LCG

Mine and Unexploded Ordnance - UXO

National Development Framework - NDF

Transitional Assistance for Afghanistan (TAPA)

United Nations Assistance Mission to Afghanistan (UNAMA)

United Nations Children's Fund (UNICEF)

United Nations Development Programme (UNDP)

United Nations High Commissioner for Refugees (UNHCR)

United Nations Office for Drugs and Crime (UNODC)

World Bank - WB

World Food Programme (WFP) 


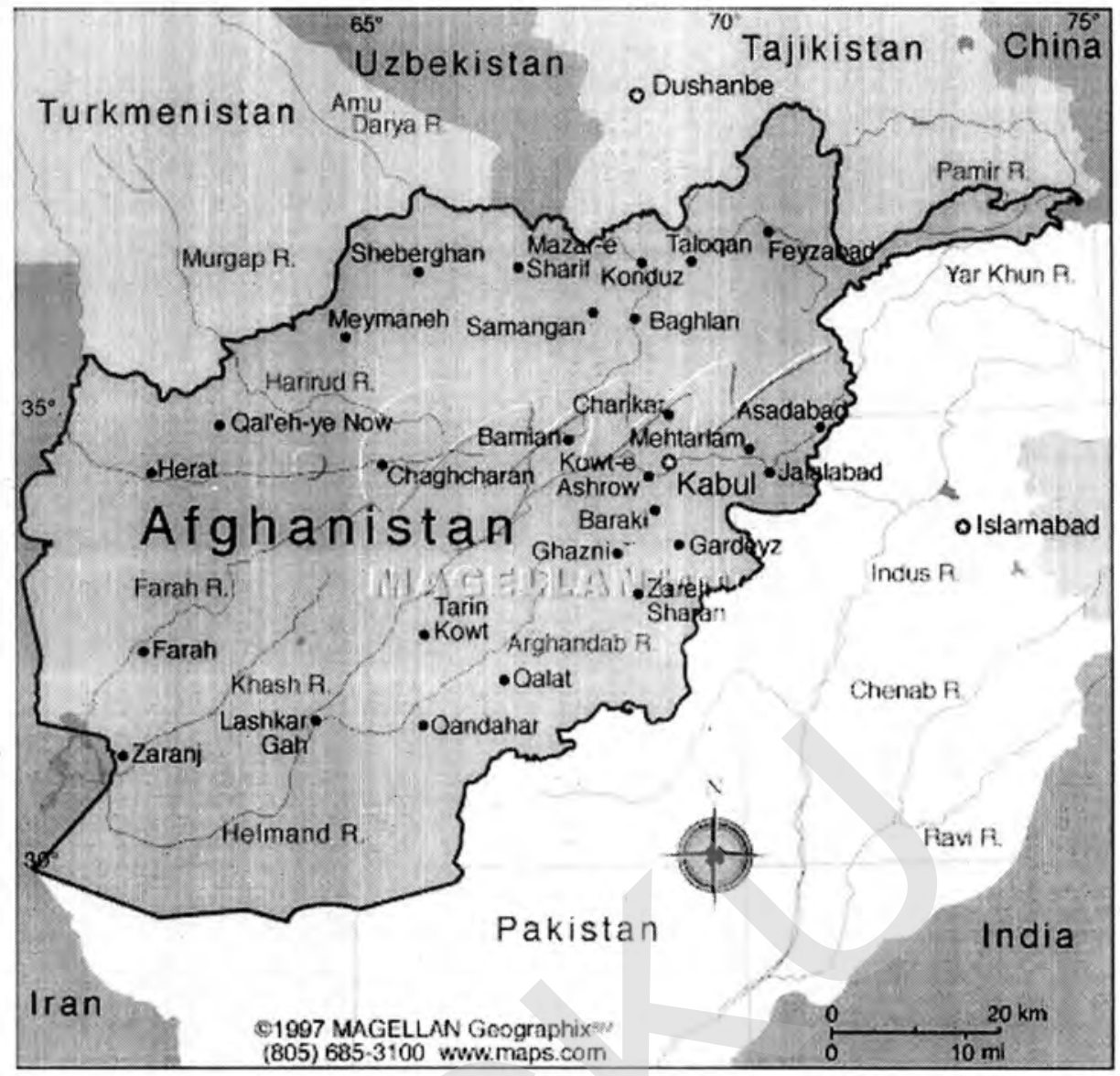




\section{EXECUTIVE SUMMARY}

The December 2001 Bonn Agreement set the milestones for moving towards a stable and democratically elected government in Afghanistan by 2004.

EU support for Afghanistan is set firmly within this context. The July 2002 General Affairs Council reiterated the importance of respecting human rights, including the rights of women, treating all minorities fairly and tackling drug production and trafficking.

At the January 2002 Tokyo Conference, the European Commission pledged about $€ 1$ billion over five years, subject to the annual approval funds by the budgetary authority. In 2002, about $€ 207 \mathrm{mn}$ will be spent on recovery and reconstruction, plus $€ 73 \mathrm{mn}$ from ECHO. A total of about $€ 400$ million has been earmarked for the period 2003-04. In addition, there will be continued humanitarian assistance from ECHO - up to $€ 55$ million is likely in 2003.

The establishment of the Afghanistan Transitional Authority (ATA) is a welcome step forward in the Bonn process. The ATA has taken significant measures to create a stable macro-economic framework and put in place a firm government structure to prioritise and manage the flow of aid from the international community.

Nonetheless, Afghanistan continues to face a challenging political, economic and social situation. The ATA needs to strengthen its legitimacy (especially in the provinces). The economy remains one of the poorest in the world, and the rate of child mortality and adult illiteracy are amongst the highest in the world. Equally, the latest United Nations Office for Drugs and Crime (UNODC) report indicates that opium poppy production has increased substantially in 2002.

Against this background, it is important for all donors to work closely with the ATA to ensure that aid flows are used efficiently and effectively, and have a tangible impact "on the ground" as quickly as possible.

In 2002, the Commission has channelled some of its funding directly to NGOs (especially in hard to reach localities, and sectors with a strong NGO presence). As the Afghanistan Transitional Authority continues to develop an increasingly robust coordination structure, the Commission believes it will be important to increasingly channel development resources through Government structures.

The Country Strategy Paper highlights the areas where the Commission can make a significant contribution to stability and poverty reduction by supporting the process of recovery and development.

It reflects the priorities identified in the National Development Framework and the October 2002 Development Budget, as well as focusing on those sectors where the European Commission has expertise. 
The European Commission will therefore concentrate on four key areas for the period 2003-04:

- Capacity building within the Afghanistan Transitional Authority linked to strong continued support for the recurrent budget. $€ 15$ million has been earmarked to build capacity within key Government Ministries and help drive public administration reform, including by strengthening the revenue position. This will be complemented by continued support for the Trust Funds - notably the World Bank Afghanistan Reconstruction Trust fund - established to help finance the recurrent budget i.e. the salaries of key Government workers such as teachers and health workers. Over $€$ 80 million is planned;

- Rural development and food security. Over $€ 100$ million has been earmarked to tackle rural poverty through labour intensive work schemes, including irrigation, promoting alternative livelihoods, improving access to local markets, and promoting women's active participation in the rural economy. The European Commission office in Kabul will play a lead agency role in rural livelihoods;

- Economic infrastructure. Over $€ 90$ million has been earmarked to finance infrastructure projects, including the reconstruction of the Kabul-Jalabad-Torkham road;

- In health, $€ 25$ million has been earmarked to help reduce infant and maternal mortality by providing a basic health care package, including by continuing to finance rural clinics previously supported through ECHO;

The remaining $€ 80$ million will be spent on tackling some of the cross-cutting issues which are key to recovery and poverty reduction. The key elements of this are:

- continued support for demining ( $€ 20$ million);

- continued support for civil society, and also social protection for the most vulnerable ( $€ 14$ million);

- promotion of regional co-operation, including on refugees ( $€ 14$ million);

- specific support to help smooth the return of all refugees ( $€ 10$ million);

- additional support for tackling poppy production ( $€ 10$ million);

Finally, the Commission will play a role on some of the major cross-cutting issues facing Afghanistan - the promotion of democracy and human rights, including the role of women. In order to reinforce the gender approach in the areas mentioned above, at least $2 \%$ of the overall amount available under this CSP will be devoted to specific women's projects. 


\section{INTRODUCTION}

This Country Strategy Paper sets out the long term objectives of the European Commission's development assistance to Afghanistan. It identifies the sectors where the Commission will focus its support and explains how the Commission's approach will contribute to poverty reduction through recovery and reconstruction. The country strategy covers the period 2003-2006. Progress against the Bonn agreement will reviewed in 2004, and funding has not therefore been programmed beyond 2004 . Member States will be consulted as funds for beyond 2004 are programmed.

It begins by setting out the political, social and economic situation and explores the challenges that Afghanistan will face in moving towards a stable democracy as anticipated by the Bonn agreement. The paper then highlights the areas where the Commission can - alongside other donors - make a significant contribution to the process of reconstruction.

This builds on the interim strategy of December 2001 on which the Commission's interventions for 2002 were based.

\section{THE EU/EC CO-OPERATION OBJECTIVES}

The December 2001 Bonn Agreement set the milestones for moving towards a stable and democratically elected Government by 2004 . It underlined the importance of respecting human rights, including the rights of women; treating all minorities fairly; and tackling drug production and trafficking.

EU support for Afghanistan is set firmly within this context. The December 2001, April, July and December 2002 General Affairs Councils agreed that overall objectives for the $\mathrm{EU}$ and the EC in Afghanistan were to:

- Promote the Bonn Agreement and its implementation by all groups.

- Restore stability in Afghanistan as part of the international community efforts to crisis prevention.

- Provide support for civil, social and military structures and services and aid for all those in need, especially refugees and displaced persons.

- Promote democracy and the functioning of public institutions and thus promote the protection of Human Rights.

- Give special attention to the inclusion of women as equal partners in Afghan society.

- Insist that the Afghan authorities, in co-operation with the IMF, establish an effective and comprehensive macro-economic and monetary framework to ensure sustainable economic development and effective use of donor funding. Give special attention to the inclusion of women in Afghan society.

- Reinforce the fight against illegal drugs and terrorism.

- Promote cooperation with neighbouring countries in the successful reconstruction of Afghanistan. 
At the January 2002 Tokyo conference, the Commission pledged about $€ 1$ billion over five years in support of Afghanistan. This total indicative envelope is subject to yearly approval of funds by the budgetary authority. This very sizeable pledge underlines the determination to provide medium term support. As Mr Christopher Patten, Commissioner for External Relations in the European Commission, said to the European Parliament in late 2002: "I am determined to ensure that the European Commission remains fully engaged in Afghanistan even if world attention shifts to other places of conflict and post-conflict rehabilitation."

The establishment of a "deconcentrated" EC Office in Kabul from February 2002, and the appointment of an EU High Representative to Afghanistan, has already ensured that this financial pledge translates into early and tangible progress on the ground.

\subsection{Key risks to success}

The establishment of the Afghanistan Transitional Authority (ATA), following the Loya Jirga (a traditional mechanism for conflict resolution and leadership selection), is a significant first step towards implementing the Bonn agreement. Nonetheless, it remains an ambitious agenda and the political, civil and physical reconstruction of Afghanistan will take many years. Key risks to the process include:

- The political situation remains unstable.

- Central Government's grip on the regions is weak - there is a risk of fragmentation.

- The fragile internal security situation continues to limit the impact of the aid programme outside Kabul.

More specifically:

- The weak institutional capacity of the transitional Government undermines the effective use of aid flows;

- Unless the building blocks for stable macro-economic framework are more rapidly put in place, there is a risk of moving towards unstable budget deficits and high inflation;

- Weak agricultural prices, limited options for alternative income and lack of law and order in certain provinces are encouraging increased poppy production.

The ATA - with donor support where appropriate - needs to minimise these risks as much as possible. For the donor community, including the Commission, a key aspect will be ensuring that aid flows are used efficiently and effectively. This will help to reinforce the Government's legitimacy and promote widespread support for the Bonn process. Timely disbursement of funding commitments will continue to be critical.

\section{Afghanistan's Policy Agenda}

The Afghanistan Transitional Authority, in consultation with donors and NGOs, has now established some of the basic government policies needed for restoring peace, stability and growth to Afghanistan. They form a welcome and clear basis for national policy after the vacuum of the past twenty years. There are three main strands to the policy agenda: 
- The National Development Framework (NDF) setting out the broad development challenges and aspirations of the ATA in twelve core priority sectors.

- The National Development and recurrent budget. The Development Budget helps to establish expenditures priorities across the 12 key sectors;

- The emerging Government structures and mechanisms to ensure the NDF and Development Budget (DB) is implemented effectively.

However there are other fundamental gaps that remain in the government's policy agenda that are only now being tackled, for example: the absence of a comprehensive public administration reform; the lack of clarity about the relationship between the centre and the provinces and, lastly, refusal by provinces to pass on customs revenue to Kabul.

\subsection{National Development Framework}

The National Development Framework (NDF) comprises three main Pillars:

- Pillar 1: Human Capital and Social Protection.

- Pillar 2: Physical Infrastructure

- Pillar 3: Trade and Investment, Public Administration and Security

Pillar 1 has five elements that seek to protect and develop the human and social capital of Afghanistan, especially women and girls. Afghanistan requires continued humanitarian support, especially in helping refugees and internally displaced persons return to their place of origin, and addressing the basic needs of the drought affected population. In addition, basic education and health services urgently need to be put in place. In health, key priorities include extending geographic coverage of clinics and hospitals and ensuring delivery to all of the Essential Primary Healthcare Package. In education, primary and secondary education needs to be expanded rapidly with particular emphasis on girls and vocational training for men and women. Rural livelihoods protection addresses the needs of the $85 \%$ of the population living in rural areas which have been ravaged by drought, war and emigration. Lastly, the area of culture, media and sport is central to promoting democracy and a vibrant civil society.

While reliance on NGOs and UN in this pillar continues, the government is correctly taking a stronger role - on coordination of humanitarian assistance and, for education and health, a more direct management role - as are the beneficiary communities themselves.

Pillar 2 focuses on transport and telecommunication, energy and mining, urban management and natural resource management (largely agriculture but also marble, precious stones, gas/oil, coal, etc). It is an ambitious plan of reform and public works projects that needs national and international contractors if it is to succeed. The obvious choices are neighbouring country's contractors (e.g. Pakistan, northern NIS, Iran and Saudi.

Roads are a key priority - providing both essential transport links and potential cash for work benefits. The priorities include policy reform and compliance with legislation, general road maintenance, reconstruction of international links (e.g. Kabul-TorkhamPakistan) and reconstruction of internal trunk roads (e.g. Herat/Kabul ring road). 
The NDF envisages leaving Telecommunications largely to the private sector, with the Government simply creating the right regulatory framework.

In energy and mining, the short term objective is to repair and upgrade existing generation and transmission capacity. In the longer term, the NDF explores the options for restarting coal production and utilising natural gas reserves and pipelines. In agriculture, the emphasis is on inputs (seed industry) and extension work and not on rural livelihoods which is addressed under Pillar I.

In urban management, the short term goal is immediate repair through cash for work programmes. This has been quite successful in 2002 but the long term challenges of large scale rehabilitation and maintenance through cost recovery for urban transport, electricity, sanitation and water supply services has not been tackled substantively (outside of the major electricity and sanitation projects for Kabul). The lack of overall plans and the collapse of large-scale facilities have led to too much direct well digging which is depleting resources. For urban drinking water and sewage, city-wide approaches need to be developed to use existing resources effectively and to avoid health problems (no sewage collection).

Pillar 3 concentrates on trade and private sector development, public administration and security/rule of law. The short term challenges are substantial. For example, without customs revenue collection reform, central government will never finance its own budget. Without public administration reform, the civil service will be unable to deliver the services the citizens of Afghanistan deserve. Without security, citizens' lives will never improve and the risk of slipping back into war will remain high.

The policies proposed in these areas are becoming more rigorous - conditions are being placed on governors, a national army solution is taking shape, demining and police are progressing well - but much remains to be done.

The following diagram (overleaf) prepared by the Assistance Coordination Authority of Afghanistan (AACA) presents the twelve priority programmes within these Pillars.

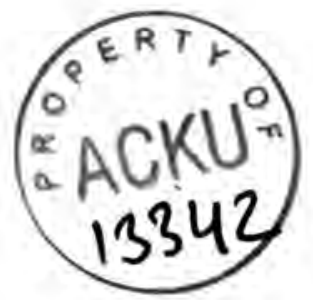




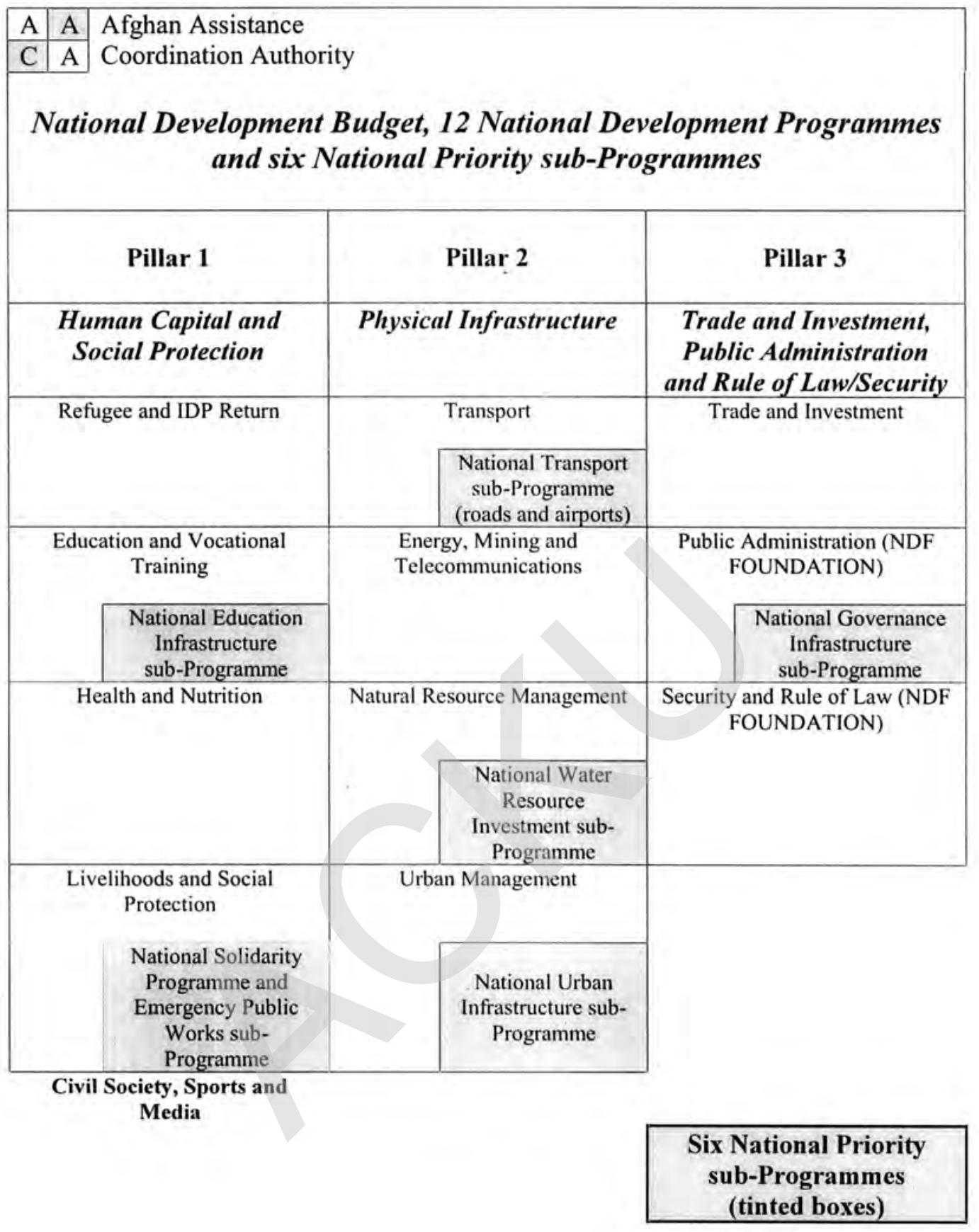

4 Cross-Cutting Themes: Poverty Reduction, Gender and Environment 


\subsection{The National Development and Recurrent Budget: Setting Priorities}

In October 2002, the ATA presented both its Recurrent and Development Budget for 2002/2003. The National Recurrent Budget represents the ATAs running costs, including the salary costs of key public sector workers. A weak revenue base reflecting the failure of regions to submit customs and other revenues to central Government - leaves a significant financing gap which is being met through donor funding via the World Bank administered Afghanistan Reconstruction Trust Fund $(\mathrm{ARTF})^{\prime}$.

Despite substantial donor contributions to the ARTF, a financing gap remains for the current budget year (March 2002- March 2003), and the ATA is likely to continue to rely on significant external funding for 2003/2004. In the medium term, it is not sustainable to rely on external financing for the recurrent budget, and there is also an opportunity cost as scarce donor funds are lost to more productive investment. For this reason, great emphasis will be placed on increasing customs revenue transmission to central government in 2003. The importance of this is discussed further in the economics section below.

The National Development Budget (NDB) sets expenditure priorities across the 12 major sectors of the economy for $2002 / 2003$ and begins to identify the funding available for each sector. The development budget builds on the NDF by proposing that available resources are allocated across the three major pillars in the following way:

- Pillar 1 (Humanitarian and Human and Social Capital):

$45 \%$

- Pillar 2 (Physical Infrastructure):

- Pillar 3 (Trade and Investment, Public Administration and Security): $20 \%$

The ATA has proposed that each donor should focus their activities in no more than three sectors ${ }^{2}$ and, in addition, that $50 \%$ of each donor's total expenditure (excluding any support for the recurrent budget) should be allocated to one "major" sector. This approach is intended to promote effective coordination, maximise the tangible impact of each donor's contribution, and enable donors to play a pro-active role in their chosen sector.

Table 1 below summarises the available resources and funding gaps across the twelve sectors. These reflect the difference between committed resources and the ATAs development goals for each sector. However, it should be stressed that the figures are preliminary and will be updated as Ministry of Finance receives more detailed information about donor priorities for 2003. Key points worth noting are:

- Although the Development Budget is based on the current budget year (March 2002 - March 2003), many of the ATAs objectives will take time to achieve;

(1) I The Afghanistan Reconstruction Trust Fund was established on May 13 2002. The World Bank are also responsible for monitoring the use of funds, and have appointed an in country team from Price Waterhouse Coopers to ensure funds are used for their intended purpose.

(2) 2 This is in addition to any support to the recurrent budget, and therefore consistent with the Commission's approach. 
- This, alongside the ATAs estimates of the overall funding gaps, reinforces the need to set clear priorities (which do not change over time);

- As might be expected, existing donor activity is focussed on health, rural recovery and supporting refugee return;

- Within the social sectors, education appears to have the greatest funding shortfall;

Once the Development Budget fully reflects donors' expenditure plans, it will form an extremely useful planing tool for co-ordinating donor support to different sectors.

\subsection{Implementation Mechanisms}

In terms of structuring, co-ordinating and overseeing the implementation of the NDF, the key Government structures are:

- An increasingly strong Ministry of Finance which oversees both the recurrent and development budget. The Development Budget plays a key role in bringing Ministries together to establish overall priorities;

- The Afghanistan Assistance Coordination Authority (AACA) ensures external IFI and donor assistance is focused on the key NDF priorities, and will take on responsibility for ensuring the development budget fully reflects donor expenditure plans.

Table 1: National Development Budget (March 2002-March 2003)

\begin{tabular}{|c|c|c|c|c|}
\hline \multirow{3}{*}{\begin{tabular}{|l|} 
National Programmes \\
\end{tabular}} & \multicolumn{4}{|c|}{ Total (\$ US thousands) } \\
\hline & \multirow[t]{2}{*}{ Budget } & \multirow[t]{2}{*}{ Resourced } & \multicolumn{2}{|l|}{ Unmet } \\
\hline & & & Total & $\%$ \\
\hline \multicolumn{5}{|l|}{ PILLAR I } \\
\hline Refugee Return (NDP Code: 1.1 ) & 465,262 & 207,307 & 258,759 & $56 \%$ \\
\hline Education (NDP Code: 1.2 ) & 508,555 & 90,685 & 417,870 & $82 \%$ \\
\hline Health and Nutrition (NDP Code: 1.3 ) & 291,970 & 143,600 & 148,370 & $51 \%$ \\
\hline $\begin{array}{l}\text { Rural Livelihoods } \\
\text { Social Protection (NDP Code: } 1.4 \text { ) }\end{array}$ & $\begin{array}{l}486,976 \\
53,788\end{array}$ & $\begin{array}{l}298,620 \\
3,155 \\
\end{array}$ & $\begin{array}{l}188,356 \\
50,633\end{array}$ & $38 \%$ \\
\hline Cultural/Media/Sport (NDP Code: 1.5 ) & 150,740 & 14,008 & 136,732 & $91 \%$ \\
\hline Sub Total & $1,957,291$ & 757,375 & $1,199,916$ & $61 \%$ \\
\hline \multicolumn{5}{|l|}{ PILLAR II } \\
\hline $\begin{array}{l}\text { Transport } \\
\text { Telecommunications (NDP Code: } 2.1 \text { ) }\end{array}$ & $\begin{array}{l}311,189 \\
168,000\end{array}$ & $\begin{array}{l}35,729 \\
1,000\end{array}$ & $\begin{array}{l}275,460 \\
1,000\end{array}$ & $\begin{array}{l}87 \% \\
98 \%\end{array}$ \\
\hline Energy, Mining (NDP Code: 2.2 ) & 65,700 & 0 & 65,700 & 100 \\
\hline Natural Resources (NDP Code: 2.3 ) & 171,141 . & 43,291 & 127,850 & $75 \%$ \\
\hline Urban Management (NDP Code: 2.4 ) & 159,503 & 25,000 & 134,503 & $84 \%$ \\
\hline Sub Total & 875,533 & 105,020 & 770,513 & $88 \%$ \\
\hline \multicolumn{5}{|l|}{ PILLAR III } \\
\hline Trade - Investment (NDP Code: 3.1 ) & 33,000 & 1,000 & 32,000 & $96 \%$ \\
\hline Public Administration (NDP Code: 3.2 ) & 295,841 & 32,471 & 245,398 & $82 \%$ \\
\hline Security/Rule of Law (NDP Code: 3.3 ) & 21,700 & 0 & 21,700 & $100 \%$ \\
\hline Sub Total & 350,451 & 33,471 & 299,098 & $85 \%$ \\
\hline
\end{tabular}

Note: Figures represent best working estimates for 2002 and only provisional budget allocations for 2003 .

- Agreement that Afghanistan should move towards a Consultative Group (CG) structure. The first full CG meeting will be scheduled for March 2003 and then annually thereafter. At the local level, there will be twelve Local Consultative Groups (LGCs) to support each programme area in the Development Budget meeting regularly over the year. Each LCG will be co-chaired by the relevant Ministry and a lead agency/ donor. The expectation is that the lead agency will have 
substantial expertise and play a major role in policy development, as well as being a major financial contributor to the programme area. A gender advisory group will determine how gender issues will be mainstreamed into the work of each group.

- A series of Capacity Building Groups are being established in priority ministries to bring together the most skilled staff to focus on implementing core tasks (strategy and programmes), to train and build capacities in the rest of ministry and to extend core capacities from Kabul into the provincial structures. At the provincial level, the governors are the key coordination point with a series of nine representatives of the key line ministries - it is upon this basic structure that donors will focus provincial capacity building efforts.

- A longer-term Public Administration Reform programme is being discussed for restructuring government and retrenching civil servants but is slowed by the political constraints that exist on cabinet.

- The ATA is using where possible Trust Funds to ensure coherence of donors activities in key areas, including the ARTF and two other funds for police/judiciary and the military. By using the trust funds, fees and procedures are harmonised. All donors agree that the ARTF is the preferred multilateral mechanism for channelling budgetary support to the Government. Looking to the future, donors have also agreed that it is important to increasingly channel development resources through Government structures, and to ensure that all expenditure plays a role in achieving Government priorities. In 2002, some donors - including the European Commission - have worked directly with NGOs (especially in some hard to reach localities, and sectors with a strong NGO presence).

- The ATA has established a central procurement capacity to standardise procurement among donors and to strengthen the financial control and audit systems in government. International companies have been brought into to both undertake tasks in the short term while strengthening government capacities in these areas for the longer term.

In summary, the ATA has now developed a structure to co-ordinate donor support, and put in place a policy framework for planning how best to target available donor funding on priority sectors and activities.

\section{Political, Economic and Social Situation}

Nonetheless Afghanistan continues to face a difticult political, economic and social situation. The recently established Afghanistan Transitional Authority has yet to fully establish its legitimacy (especially in the provinces), the economy has been severely affected by the last two decades of internal strife, and the rates of under 5 mortality and illiteracy are amongst the highest in the world.

\subsection{Political Situation}

The 2002 Loya Jirga was a welcome step forward in the Bonn process and successfully appointed the new Afghan Transitional Administration headed by Hamid Karzai. The former King was appointed Father of the Nation. But the ATA faces enormous challenges over the next two years: 
- A new constitution must be written and approved. Decisions will need to be made on difficult issues such as the balance between secular and Islamic society, the rights of women and the role of central versus regional government;

- The legal, logistical, and cultural grounds for "free and fair" elections must be prepared;

- A national armed force of up to 70,000 must be trained and deployed while up to 200,000 faction-based soldiers are demobilised;

- A Human Rights Commission will need to educate, investigate and potentially adjudicate on a variety of human rights questions;

- Donors and government must collaborate to design and implement an effective multi-level process of gender mainstreaming;

- Up to 3 million returning refugees will need to absorbed;

- Poppy production must be tackled.

- The civil service must be streamlined and reformed to create a modern, efficient and independent administrative body.

This would be challenging agenda under any circumstances. But continued political volatility leaves the outlook even more uncertain. The collapse of the Taliban permitted the return of many of the regional commanders and warlords involved in the civil war of the 1990s. Many commentators believe that the Loya Jirga failed to halt their influence, thus restricting central Government's ability to drive change, to create a strong cohesive state, and to reach out to the provinces.

The terrorist attacks and assassinations witnessed throughout 2002 highlight the fragility of the internal security situation. Not only does this pose a potential threat to the Bonn process and redevelopment, but the different regional factions also limit the impact of the international aid programme outside Kabul. Thus an immediate challenge for the ATA is to create a more secure internal environment and to find an effective way of working with the provinces.

Within this context, tackling drugs is likely to prove a particular challenge. In 1999 Afghanistan was the largest producer of opium in the world, accounting for $70 \%$ of the world total. This dropped to $25 \%$ in 2000 following a ban on production by the Taliban. After the fall of the Taliban, opium production re-started despite a ban imposed in January 2002 and an eradication programme that began in April 2002. While the eradication programme destroyed about $10 \%$ of total production, the October 2002 Poppy Survey of the United Nations Office for Drug control (UNODC) shows a strong resurgence in cultivation.

Eradication alone is unlikely to curb poppy cultivation. A much more holistic approach is required, addressing alternative livelihoods, access to credit, institution building and demand reduction. Experience elsewhere in South East Asia also suggests that a sustainable solution cannot be achieved overnight - it will require long term commitment of politicians, of law and order and of funding.

The weak public administration will be a further major constraint on the ATA's ability to drive through change. The current civil service is too large, with numerous 
Government Departments with overlapping responsibilities. The legacy of Soviet style central planning and poor salaries have also led to an inadequate supply of skilled professional staff who are able to develop robust policy frameworks. Of particular concern is the weak Ministry of Women's Affairs. Promoting gender equity and equality is a priorityand, therefore, it is indispensable to promote structures which support women's role and involvement in the process of recovery and reconstruction and provide for a wider participation of women in the public administration.

A final complicating factor for Afghanistan is its ethnic composition. The Pashtun majority and to a lesser extent Hazaras are underrepresented in the Government while Uzbeks and Tadjiks are over-represented, especially in the security sectors. The Bonn Agreement was premised on process for power sharing which has not been fully realised through the Loya Jirga.

\subsection{The Social and Economic Situation}

Afghanistan is one of the poorest countries in the world. The current per capita GDP is estimated at $\$ 140-\$ 180-$ similar to that of Eritrea and Somalia. The international development indicators for education, health and mortality further underline Afghanistan's impoverished circumstances, and the constraints faced by women and girls in accessing basic services. About four fifths of the population is rural and the vast majority (estimates range from $60-80 \%$ ) live below the US $\$ 1$ dollar a day threshold or consume less than the Food and Agriculture Organisation's minimum daily calorie requirement. In this context, it is recommended that data as regards, population, life expectancy, income refugees/IDPs, should be broken down by sex.

The population is thought to be between $18-22$ million, and up to 25 million if refugees in Pakistan and Iran are included. Key social and development indicators are summarised in table 2 below. They highlight the huge development challenge faced by Afghanistan.

The most vulnerable groups continue to suffer from insecurity of food supply. This includes small farmers, labourers without land, internally displaced persons (IDPs), returnee refugees, ex-combatants, war widows, war orphans, and the disabled $(800,000$, of whom 200,000 were mine victims). Nonmaterial poverty as reflected in physical and social insecurity, and the marginalisation of groups for ethnic, religious and gender reasons pushes many Afghanis further down the poverty ladder. Coping strategies continue to prevent the types of starvation seen in parts of Africa but these coping mechanisms are stretched to the full, especially among the urban poor. The situation is especially difficult for women.

Prior to conflict in the late 1970s, the Afghan economy was characterised by food selfsufficiency, strong agricultural exports, and a stable macro-economic framework.

Over the past two decades, however, the productive potential of the economy has been devastated as continued conflict has destroyed infrastructure and institutions and caused extensive damage to environment. About 23 percent of the population have access to safe water and 12 percent to adequate sanitation. In 1993, only 6 percent of Afghans had access to electricity and energy consumption ( $45 \mathrm{kWh}$ per capita) was among the lowest in the world. The four year drought has been a further blow to Afghanistan's agriculture system which had made a good recovery from the war-related loss of productive capacity in the $1980 \mathrm{~s}$ and early 1990s. The drought has further aggravated environmental degradation. Since $1979,30 \%$ of forests have been lost, and many of the agricultural regions are now vulnerable to desertification. However, subject to water 
availability and management, it should be possible for Afghan agriculture to recover again.

\section{Table 2: Social and Development Indicators for Afghanistan}

\section{Development indicators at a glance}

\section{Population and Geography}

- Population: over 25 million (including refugees Pakistan and Iran).

- Population growth rate: $2.6 \%$ in 2000

- Population density: 40.7 people per sq. km

- Urban population ( $\%$ of total): 21.9

- Total Area: $652,100 \mathrm{sq} . \mathrm{km}$

- Land Boundaries: Total 5,529 km (China 76 km; Iran 936 km; Pakistan 2,450 km; Tadjikistan 1,206 km; Turkmenistan 744 km; Uzbekistan 137 km)

\section{Socio-economic Indicators}

- Average life expectancy: 44 years.

- $60-80 \%$ thought to have an income the US \$ 1 dollar a day benchmark.

- Illiteracy rate: 64 per cent (i.e. nearly two-thirds of Afghan adults).

- Illiteracy rate for adult males: $48.1 \%$ of males over 15

- Illiteracy rate for adult females: $78.1 \%$ of females over 15

- $70 \%$ of Afghan population is malnourished

- Just over one in ten Afghans have access to improved water resources.

- Primary school enrolment ratio for boys: 39 per cent

- Primary school enrolment ratio for girls: 3 per cent

- Only 7 per cent of 4.4 million children of primary school age are covered by aid agencies.

\section{Women and Children in Afghanistan}

- A woman dies every 30 minutes in Afghanistan due to pregnancy related causes (maternal mortality rate of $1,700 / 100,000$ live births).

- One in every four children born will die before they reach five years old.

- Clean water and vaccine campaign could prevent about half these deaths.

- One of every two surviving Afghan children is malnourished.

- One of every two surviving children is stunted in height.

\section{Refugees / Internally Displaced People (IDPs)}

- One fifth of Afghans are refugees or internally displaced

- Another 4 million people are dependent on food elsewhere.

- Refugee returns are accelerating dramatically - almost 2 of the 5 million refugees could return in 2002 alone - and will overload the system.

- Internally displaced Afghans in the wake of the recent conflict have risen from 900,000 to an estimated 1.1 million and stood in September 2002 again at around 800.000 .

Sources: UN agencies and World Bank 2002. 


\subsection{The Emerging Economic Policy Framework}

The ATA has taken welcome steps to put a stable macro-economic framework in place to support sustainable growth. As in the other areas, the challenges are substantial, but good early progress has been made, notably:

- The October 2002 development budget provides the framework for prioritising reconstruction efforts across different sectors, and for effective donor planning and coordination. The government is also starting to pressure provincial governors to pass revenues back to central government;

- The ATA is committed to maintaining a balanced budget, with no deficit financing;

- A new currency has been introduced, and is expected to be fully operational by end 2002. This should provide a robust anchor for future monetary policy. Early indications are that this is going well although it is unclear if the depreciation during the change over (exchange rate to the dollar has fallen $50 \%$ ) is a temporary function of the change-over or a structural readjustment.

- A new Central Bank law is imminent. This will underpin a strong, autonomous Central Bank with the key objective of maintaining price stability;

- The first privatisation - in the telecom sector - took place in 2002 and a further private franchise is expected to take place by early 2003 .

Looking ahead, key issues will include:

- Maintaining a balanced recurrent budget. The Government continues face a funding gap for 2002/03. Though additional donor pledges have helped to close this significantly, a funding gap of up to about US $\$ 90$ million remained in mid October 2002. The Government will need to stick to its pledge of no Central Bank financing of the deficit to retain confidence in the new currency and avoid strong inflationary pressure;

- Key to this will be tangible progress towards boosting Government revenues and thus a self-financing recurrent budget. At present, many custom revenues are not passed to Central Government. The ATA are committed to tackling this, and to developing a sounder revenue base;

- Effective management of development aid flows will also be key both to ensure the funds deliver much needed improvements in basic services and infrastructure, and to assure donors that grant funds are being well used.

- Taking advantage of the low level of external debt by accessing concessional loans from early 2003. Arrears to the World Bank and Asian Development Bank are about US \$ 45 million. Several donors including Norway and DFID have offered to help clear these arrears. This will pave the way substantial concessional loans from the World Bank. Japan has offered to help clear the small outstanding arrears to the IMF (SDR $8 \mathrm{mn}$ ) - this would open up the possibility of a future IMF post-conflict loan.

The Commission has, along with other donors, stressed the importance of establishing benchmarks - in particular to monitor progress towards a self financing recurrent budget and for reform of the public sector. The ATA will propose a broad set of benchmarks to underpin macro-economic stability at the Consultative Group meeting in March 2003. 
These will cover the banking sector, the payment system and currency reform. In addition, they may wish to consider monetary and inflation targets.

\subsection{The Refugee and IDP Issue}

The long-standing internal conflicts in Afghanistan have led to massive population dislocation. Estimates speak of up to $20 \%$ of the population being uprooted, either through internal displacement, or flight to neighbouring countries and further afield. Neighbouring countries have being hosting the "world's largest refugee population" for decades. Studies have shown that refugee and IDP populations are often overwhelmingly women and children and this has been the case in Afghanistan.

Some Afghan refugees have also been making their way to Europe, the United States and Australia, remitting monies for the subsistence of relatives and others. Massive return movements started early after the fall of the Taliban regime.

Over the last year about 1.7 million refugees are thought to have returned to Afghanistan - much higher than the 800,000 projected by the UNHCR. The majority (over Imillion) have come from Pakistan, but there have also been returns from Iran. In addition, a further 500,000 IDPs are thought to have tried to return to their place of origin.

A key issue is therefore to ensure that these returns are sustainable. Effective links between humanitarian and development aid are critical here.

The European Union is also keen to explore ways in which it could support the systematic return of Afghan Nationals - in particular to help link returns with the process of development - work being pursued by a High Level Working Group (see section 5.2 for detail).

\section{Past AND ON-Going EC CO-OPERATION}

\subsection{EC Co-operation Pre-September 11}

Over the past ten years, the EC has allocated over $€ 500$ million to Afghanistan, making it the largest single donor to the country. The support has focused on two areas humanitarian support for emergencies (especially drought relief) and support to refugees and IDPs. Support to refugees and IDPs has in part helped the 5 million refugees in Iran and Pakistan. However it has also provided substantial support in Afghanistan, largely in rural areas, to facilitate returns and to give the population the means to stay on the land, so preventing fresh waves of outward migration.

This aid has had a tangible impact - by the end of the Taliban period, the EC was supporting over 400 schools and over 200 basic health clinics, many offering services to women and girls. ${ }^{3}$ However, the biggest impact has been more on reducing extremes of vulnerability rather than actual development, which has been largely impossible given the war and then Taliban policies, especially in relation to girls' education and women's mobility and employment.

\footnotetext{
${ }^{3}$ In 2000, " the aid for uprooted people in Asia and Latin America (AUP) " for 1997-1999 was evaluated. This included a country study of Afghanistan which noted that " in addition to ensuring basic care and maintenance in the camps in Pakistan. AUP had also had a significant impact on the livelihood of uprooted people and host communities in Afghanistan".
} 


\subsection{EC Support post-September 11}

For 2002, the EC is providing over $€ 205$ million for reconstruction. In addition, the European Commission Humanitarian Office (ECHO) is providing some $€ 73.6$ million in humanitarian support to Afghanistan and to refugees in neighbouring Iran and Pakistan ${ }^{4}$. As summarised in Table 2 below, the EC's 2002 support has been targeted on the priorities identified in the three pillars of the NDF and where the Commission has relevant expertise.

This support has played an important part in stabilising Afghanistan and its government and in starting the full reconstruction effort. President Karzai in late 2002 indicated the government's strong satisfaction with this EC support to date: "I express my deep personal thanks and the gratitude of the people of Afghanistan for the level of commitment to Afghanistan's reconstruction shown by the people of Europe, especially through the European Commission's reconstruction programme. The European Commission has moved with remarkable speed and responsiveness to our priorities to implement its projects."

Some indicators of achievement for EC reconstruction from this first period are:

- massive jobs creation is taking place with over three million person days over twelve months.

- the Kabul-Jalalabad-Torkham road is reopened.

- urban and rural assets are now being rehabilitated (e.g. irrigation canals and urban sanitation services) in poor rural areas (14 out of 32 provinces) and major urban centres (Herat, Mazar, Kandahar, Jalalabad, Bamyan and Ghazni).

- 450 girls and boys schools are back in operation and functioning through EC support

- 238 health clinics and three hospitals are functioning through EC support.

- EC is one of the largest funders of the demining programme to rid Afghanistan of this menace in seven years.

- EC is the largest financier of government, putting male and female teachers, nurses, doctors and policeforce back to work for the citizens of Afghanistan.

The EC reconstruction support has been provided through a number of instruments. Of particular importance at the start up in 2002 was the $€ 6.7 \mathrm{mn}$ from the Rapid Reaction Mechanism in ensuring a rapid response to Afghanistan's initial reconstruction needs, including emergency support to restart government services (including salaries and building repair), support to civil society and media and emergency infrastructure rehabilitation through ISAF. This support bridged the period until the full reconstruction effort got underway on the ground in summer through the long term budget lines of Food Security, Aid to Uprooted People and Asia/Latin America.

(4) 4 This includes a request for a further $€ 10$ million from the emergency reserve that is not yet confirmed. Between September 2001 and the end of 2001, ECHO also provided $€ 31$ million in humanitarian support. 
Table 3: European Commission Aid to Afghanistan in 2002

\begin{tabular}{|l|r|}
\hline Pillar 1: Human and Social Capital & Million $€$ \\
\hline Health & 12 \\
\hline Social protection, civil society and media & 9 \\
\hline Repatriation of refugees (JAI) & 3.6 \\
\hline Rural recovery and livelihoods & 70 \\
\hline Pillar 2: Physical Infrastructure & 10 \\
\hline Economic Infrastructure - roads and electricity supply & 8 \\
\hline Urban Infrastructure - renewal six cities & 12 \\
\hline Pillar 3: Trade and Investment, Public Administration and Security & 52.5 \\
\hline Public administration: reform, capacity building and trade & 4 \\
\hline Support to budget - Trust Funds & 10.4 \\
\hline Police and security & 15.3 \\
\hline Demining & $\mathbf{2 0 6 . 8}$ \\
\hline Other - studies, pilots and TA & 73.6 \\
\hline Humanitarian support (ECHO) (see note) & $\mathbf{2 8 0 . 4}$ \\
\hline Total reconstruction and humanitarian support. & \\
\hline
\end{tabular}

This includes $\epsilon 10$ million requested by ECHO from the emergency reserve.

\section{PRIORITIES FOR $2003 / 2004$}

\subsection{Principles}

The EC response strategy reflects the political, economic and social situation in Afghanistan and assessment of how the Community can best contribute to poverty reduction and the long term goal of Afghanistan's stabilisation and development. Planned activities for 2003/04 therefore build on:

- The priorities identified in the National Development Framework and the emergent Development Budget;

- The need to reduce poverty - in particular through the promotion of rural recovery where over $80 \%$ of the population live;

- The EC's expertise in certain sectors where it has a track record of delivery and instruments which can efficiently address the needs set out in the development budget.

- The need to address the major cross cutting issues that will otherwise compromise sustainable development. Most notably gender, refugee return, poppy production, demobilisation, demining, and protecting the environment.

- The need for a smooth transition from EC humanitarian to reconstruction support.

Nonetheless, given the huge level of need in Afghanistan, additional factors also need to be considered to target European Commission support as effectively as possible. These include:

- Focusing on a limited number of sectors, in line with EC policy not dissipate its response strategy across too many sectors.

- Close coordination with other donors. 
- Giving sectoral interventions a geographic concentration, where possible.

- Ensuring effective gender mainstreaming with well defined objectives and targets in as many intervention areas as possible.

The National Indicative Programme for 2003-04 (attached) therefore focuses on four major areas - rural recovery and food security; public administration reform and support for the budget; economic infrastructure and health - and to develop programmes in these areas within the framework of the government's "priority programmes" as set out in the $2002 / 2003$ budget.

The EC will strive to concentrate our planned activities for health and rural recovery and food security in specific geographic areas. There are several ways in which this could be approached, including by:

- Building on the geographic coverage of ECHO (e.g. focusing on those areas where ECHO have put basic health care facilities in place).

- Concentrating on those areas with the greatest refugee returns to promote sustainability (Kabul and North Kabul).

- Concentrating on those areas of greatest immediate need where the drought continues (Southern Afghanistan).

- Concentrating on those areas with the greatest poppy production to promote alternative livelihoods (e.g. Nangarhar).

In making final decisions the EC will also need to take the internal security situation into account, in order to maximise the impact and effectiveness of EC assistance aid.

\subsection{Cross Cutting Issues}

Many of the problems facing Afghanistan impact across all sectors and activities. Those issues that will impact heavily on the $\mathrm{EC}$ 's poverty reduction goals and reconstruction efforts include the role and the status of women, the sustainability of refugee and IDP returns (which is linked to internal security), the eradication of poppy and demining.

Other cross-cutting issues will also require attention if sustainable development is to be assured. These include the promotion of human rights; the protection of children and other vulnerable groups; the participation of local communities in recovery and reconstruction activities; the protection of the environment; and issues related to migration and trafficking in human beings.

In broad terms, the EC aims to address these cross-cutting issues through:

- Project design - ensuring that specific projects take account of these concerns. No project is programmed without their impact on cross cutting themes being incorporated.

- Financing specific projects - where the cross cutting theme cannot be fully addressed through project design, for example demining where specific projects are needed. 
The remainder of this section discuses the areas where the Commission will be especially active, and where there will be funding for specific projects.

For refugees and IDPs, EC assistance will continue to focus on the safe return of families to their place of origin by providing them with basic necessities - food, shelter, water. EC reconstruction support will help to build on the sustainability of return by promoting health, rural recovery and the wider reconstruction of the economy. However, the internal security situation continues to threaten the sustainability of return by preventing individuals from returning to their place of origin, and placing substantial pressure on the urban centres attracting the majority of returnees. For this cross cutting theme to be addressed effectively, the EC has an interest in several policy issues, including:

- Supporting the ATA in its discussions with neighbouring countries, especially Pakistan, to develop a comprehensive and phased approach to the return issue.

- Addressing, with ATA, the issue of urbanisation that has come with the large scale return movements.

- Establishing, with ATA, priority areas where targeted support for uprooted people will make early impact with regard to sustainability.

- Working with ATA on the return of qualified nationals, including those from Europe.

The Seville European Council also called for the urgent adoption of a repatriation programme which included "the best possible facilities for early return to Afghanistan". The Presidency paper endorsed by the 27-28 November JAI Council includes a Commission led "Afghanistan Co-ordination Return Group (ACRG)". This will share information about Member States' return arrangements and help to promote a smooth return process (potentially including for those who fail to qualify to stay in a Member State). The co-ordination group is also expected to consider the security situation and the sustainability of returns. The initiative also foresees the Commission having an important co-ordination role 'sur place' including by liasing with the Afghan authorities to help returnees benefit from key re-integration measures. For 2003, up to $€ 7 \mathrm{mn}$ will be available to support returns from Member States. In addition, $€ 10 \mathrm{mn}$ will be targeted on making return for all refugees more sustainable.

The EC will also play an important role in tackling drug production. The UK has, in close collaboration with the ATA and UNODC, taken the lead in external assistance in this area, and has helped the ATA to develop a strategy that embraces alternative livelihoods, institution building, effective law enforcement demand reduction, and the need for close regional co-operation. Building on its comparative advantage, the European Commission will, in close co-operation with Government and other key donors (UK, UN and US):

- Focus some of its rural recovery programmes in the areas most dependent on poppy cultivation.

- Help to build capacity within the National Security Council, the key co-ordinating body for the Government's drugs policy. 
- Use its experience of demand reduction initiatives5 in Asia and Latin America to support other donor activities in this area, taking into consideration the fact that many addicts are women and therefore culturally constrained from seeking assistance.

- Consider activities to improve coordination and co-operation with neighbouring countries as they are part of the route through which opium and heroine leave Afghanistan.

- Consider supporting any other aspects of the evolving Afghan drugs policy.

The work on alternative livelihoods must however be accompanied by effective law and order enforcement in the provinces concerned.

The status of Afghan women has been an issue of contention among different political factions and regimes for several decades. This came to the forefront of the world's attention under the Taliban administration - with the almost total exclusion of females from access to education, employment and, in some areas, even basic health care.

There is now an opportunity to enhance Afghan women's role and status within society, so that they are able to participate fully in the development of Afghanistan. Key building blocks are:

- Securing political commitment to change.

- Encouraging women's participation in the political, economic and social arenas.

- Ensuring women's role is enhanced wherever possible through EC projects such as in rural recovery, health and public administration.

- Addressing gender-related violations and human rights, including greater awareness of the rights and responsibilities of both men and women.

- Addressing conflict, poverty and underdevelopment, elements that impact dramatically on the role and status of women and their well-being.

- Addressing prevailing attitudes of individuals and communities towards women.

- Promoting access to education, employment and health.

Gender is often regarded as solely a political problem in Afghanistan but it alos constrains the country economy by limiting the role women can play. Gender will be addressed through project design (e.g. ensuring rural productivity programmes do not increase the workload on women), and well placed advocacy. In addition, the Commission will fund further projects targeted directly on women - building on actions in 2002 such as the integrated primary health care programme in three Afghan regions and the rehabilitation of essential public infrastructure used only by women and girls. In 2002 , ECHO has also funded food for work programmes targeted specifically on women.

(5) 3 See the recently concluded evaluation on the EC action against drugs ("La cooperation Nord-Sud dans la lutte contre les drogues et la toxicomanie - Rapport final", April 2002). 
Afghanistan is the most mine and unexploded ordnance (UXO) affected country in the world. There are some 200,000 survivors of mine/UXO accidents and there is a continuing injury rate of $150-300$ people per month. In addition to the human toll and loss of livestock, mines/UXO pose problems for the return of internally displaced persons (IDPs) and refugees, for agriculture and for the rehabilitation of rural infrastructure. De-mining is therefore key to the future of Afghanistan.

Mine action in Afghanistan has been extremely cost-effective with experienced UN and NGO teams. The EC is one of the largest contributors within the framework of the multi-donor Mine Action Programme and will continue to be in the future.

\subsection{Managing the Interface of Humanitarian and Reconstruction Support}

The ECHO programme has been a major source of humanitarian assistance to Afghanistan for the last ten years, and continued humanitarian support is likely to be needed for some time. But reconstruction and recovery activity is also growing.

Developing a sustainable recovery path will depend on recognising the linkages between humanitarian and development support and ensuring there is a smooth, well planned process of transition ${ }^{6}$. ECHO support promotes the return of refugees and IDPs and addresses priority needs to underpin the sustainability of return - for example, food, water and shelter. The CSP seeks to ensure that the EC reconstruction support builds on this by financing programmes (such as in rural development) that ensure the returnees have sustainable livelihoods.

The demarcation between ECHO and reconstruction support to refugees and IDPs needs however to be flexible. Unforeseen surges in returns to an area may require fast ECHO support - not only to aid returns, but also to avoid a break down in local services and infrastructure, whether through health, education or general labour intensive works support.

\subsection{Coherence and Complementarity with Other Donors}

The ATA and the donor community need to ensure that development support for different sectors is well co-ordinated, both to maximise the impact of aid flows and take advantage of different areas of donor expertise. The National Development Budget is the basis for ongoing planning and coordination of donor funding. The initiative to focus donors funds in their core areas from 2003 will further enhance coherence and complementarity.

The Commission is one of the first major donors to develop a strategy for coming years and its focal areas have been accepted by government. It is not yet clear where other donors will chose to focus their future efforts but some trends among donors are emerging in terms of level of support and interest in "leading" in the emerging CG process:

- refugee and IDP return support (EC, US and UK), education and health (Japan, US, EC and World Bank), livelihoods (EC and World Bank),

(6) "The key parameters for this are set out in the Commission Communication to the Council and European Parliament "Linking Relief, Rehabilitation and Development - an assessment". 
- infrastructure (US, EC, World Bank and Japan are leading on major roads projects with Germany being prominent in urban infrastructure).

- trade and investment (Germany and World Bank, with EC playing greater role from next year), public administration reform (World Bank, UK and EC) and Security (US, Germany, Italy and Japan).

To date, the UK has taken the lead role in helping the ATA to develop a drugs strategy (see section on cross-cutting issues) and is a leading donor in support to the recurrent budget, refugee returns and rural recovery and sustainable livelihoods. Germany is leading the international effort in security (support to Afghan police force) with Japan taking a lead on demobilisation of ex-combatants. Italy has taken the lead in coordinating the justice reform process in Afghanistan.

The EC is also striving to develop a portfolio of "EU wide" programmes with member states. The Kabul-Jalalabad-Torkham road project is being done with Sweden. The electricity rehabilitation of Kabul is being done with Germany. The Commission has also co-financed CIMIC operations with Finland and Sweden using the Rapid Reaction Mechanism. The Commission closely collaborates with the UK, Germany and Italy as regards their co-ordinating role for the drugs policy, the police reform and the judiciary. EC is cooperating with France on the health sector, in particular helping government address policy and reform options for the tertiary sector in 2003. Looking to the future, close continued cooperation with Member States will be paramount.

The United Nations (UN) also plays a key role in Afghanistan. UN activities have been co-ordinated by the United Nations Assistance Mission to Afghanistan (UNAMA) under the leadership of the Special Representative of the Secretary General. There have been two major strands to the UN's role. On the political side, the UN has provided support to establish the ATA, and will continue to have a critical role in preparing for the 2004 elections. On the humanitarian and reconstruction side, the United Nations High Commissioner for Refugees (UNHCR), the United Nations Children's Fund (UNICEF) and the World Food Programme (WFP) have played a critical role in coordinating and providing humanitarian relief. Other UN agencies - for example, United Nations Development Programme (UNDP) are playing a key role in helping to build long term capacity. As the ATA moves to a CG approach and matures its Capacity Building Groups, the need for direct support from the UN will change. However cooperation and coordination with the $\mathrm{UN}$ will continue to be critical and will remain a major feature of EC strategy. In keeping with this, the UN's 2003 programme of Transitional Assistance for Afghanistan (TAPA) will be based on the priorities established in the National Development Budget.

\subsection{Coordination}

In the first year, the huge scale of the reconstruction task faced by Afghanistan and the need for strong political commitment and leadership, led to the creation of the Afghan Reconstruction Steering Group (with its four co-chairs US, EU, Japan and Saudi Arabia) to provide strategic direction. In Kabul, the Implementation Group chaired by the Afghan Government and assisted by vice chairs (WB, IMF, ADB, IsDB, and ASG) ensured co-ordination of reconstruction activities in the field. In addition, the Afghan Support Group (ASG), which had coordinated support over the last years, continues looking at humanitarian issues and interlinkages with reconstruction.

These coordination mechanisms are now being consolidated under one Consultative Group process, as described in section 3.3. Local CG groups will be appointed for each 
of the twelve components of the NDB, headed by the Minister concerned and one or two lead agencies. The EC Office will take a lead agency role in rural livelihoods and, with others, on public administration and health. This role through the CG is crucial if the EC is to be able to implement this Country Strategy Paper. The EC office will also participate actively in the Gender Advisory Group to help ensure that gender is mainstreamed across all the Consultative Groups.

At the local level, informal coordination is also key between donors. Within EU member states, the Commission's Kabul office has recently established a European donor forum to ensure that the Commission and member states develop a co-ordinated EU approach to key issues and meetings. In addition, there is an informal donor network started post summer with the EC/EU, US and Japan to avoid misinformation (as seen in 2002 on certain issues between EU and US) and to ensure common positions can be reached where possible. With major initiatives from the US in late 2002 on expanding civil/military units outside Kabul, the need for effective and flexible coordination mechanisms will become all the more important.

The G8 is also playing an important role in co-ordinating aspects of security (both army and police), drug prevention and judiciary reform.

\subsection{Benchmarking}

The European Union's support for reconstruction and recovery in Afghanistan is set firmly within the context of the 2001 Bonn Agreement which established a roadmap for moving towards a democratically elected Government in 2004, and underlined the importance of working with the International Community to tackle opium production. In December 2002, donors and the ATA returned to Bonn and agreed to develop clear benchmarks and timelines for the full implementation of the Bonn Agreement, including in five key domains - security, administration, judicial, financial and socioeconomic. The December 2002 GAC endorsed the outcome of Bonn II and reiterated the need to make progress on drugs.In addition, the ATA have indicated that they will use the Consultative Group process to set development benchmarks. This will include creating a robust macro-economic and monetary framework and tackling difficult issues such as public administration reform and on increasing the flow of revenue from the provinces to central Government - both of which are essential for the ATA to move to self financing recurrent budget. Care will be taken to limit the number of development benchmarks (ensuring targets are feasible) and to ensure they are clear incentives to perform (engendering political commitment).

Of course, humanitarian assistance will continue to be unconditional and provided on the basis of need, respecting the principles of universality, impartiality and neutrality.

\subsection{Priorities}

In line with the principles outlined above, especially as regards coherence with the NDF and budget and complementing the activities of other major donors and IFIs, the EC has identified four major areas where it will help to promote stability ${ }^{7}$ and reduce poverty.:

- rural recovery and food security;

(7) ${ }^{7}$ Internal security and stability are prerequisite for recovery and poverty reduction in Afghanistan. 
- public administration reform and support for the budget;

- economic infrastructure;

- health.

The Commission will also provide support in a few other non-sectoral areas, but will not be a major donor. These smaller areas include de-mining, support for civil society and encouraging the emergence of the private sector by facilitating trade and helping to support micro-finance. The next three sections set out the Commission's activities in relation to the three pillars in the National Development Framework and Budget.

\subsubsection{Pillar 1 - Human Capital and Social Protection}

In humanitarian support, the EC will continue funding through $\mathrm{ECHO}$ for refugees and IDPs and those affected by drought. While it is clearly not possible to programme humanitarian assistance well in advance, it seems likely this will continue to be needed for some time.

In reconstruction, EC will focus support on the First Pillar on rural recovery, health and civil society.

Rural recovery is a key focus for EC support where substantial funds will be placed and where the EC intends to play a lead agency role through the CG. Promoting effective and sustainable rural development in Afghanistan is critical because:

- Poverty and hunger remain largely a rural phenomenon with an estimated 70 per cent of the population suffer from malnourishment:

- Rural development is the main engine for economic growth and for the development of alternative livelihoods which is crucial for reducing poppy production.

The specific objectives for EC support to rural development in Afghanistan are:

- to increase household incomes and improve public assets through labour intensive public works programmes;

- to provide, diversify and enhance 'alternative livelihoods' through investments in micro-watershed development and in micro-finance to finance the move of families away from agriculture where it is unsustainable.

- to improve access to productive assets, markets and services by communities and households - especially women - through community block grants and NGOs.

The EC is working closely with the Ministry of Rural Rehabilitation and Development (MRRD) and the Ministries of Public Works, Ministry of Irrigation and Environment and Ministry of Labour and Social Affairs and with NGOs and the private sector. At the same time, strategy development in rural development is being supported through the various Capacity Building Groups now established as part of the public administration reform programme. A key element of this work will promoting environmental sustainability.

Health is an area where the Commission has had a long-standing experience with the largest NGOs players in this sector. The overall aim is be to improve access to health 
services for as many as possible, including for the poor and vulnerable in urban areas. Support will focus on delivery of the basic health care package - namely, mother and child healthcare including reproductive health, family planning, health education and vaccination. The emphasis will be on rural areas, reflecting the needs of the country as well as the need to focus limited EC resources to ensure its impact. The objective will be reduce the high rates of infant and maternal mortality. The EC will also help to build capacity in the Ministry of Public Health $(\mathrm{MoPH})$ with the goal of strengthening policy making and improving co-operation between the MoPH and NGO or private sector providers to ensure national policy can be implemented. Cooperation with ECHO will be key in taking over financing of ECHO health partners which are in priority areas, which provide strong proposals and which are willing to move into reconstruction health support. EC support for social protection will target disadvantaged groups who have particularly suffered in the past twenty years, including groups such as women, children, war widows and handicapped persons.

Civil society plays a key part in conflict prevention, democratisation and general socioeconomic development but has been sorely neglected in Afghanistan's recent history. The EC will continue its support to facilitate the emergence of an independent media while also financing projects for cultural expression, human rights and advocacy for women and for specific disadvantaged or minority groups. Such initiatives may also be used to raise awareness of the 2004 election process.

\subsubsection{Pillar 2 - Physical Infrastructure}

Under Pillar 2, the EC will focus on economic infrastructure. It is crucial that the basic economic infrastructure of the country is reconstructed and strengthened.

By mid 2002, it became clear that the telecommunications, civil aviation, water and energy sectors will attract major IFI funding from late 2002 onwards and are sectors where the IFIs have a clear comparative advantage. The road sector however has attracted significant resources but the needs are so huge that significant financing gaps remain at the national and provincial feeder road levels.

The EC will therefore focus its economic infrastructure support in 2003 and 2004 on road construction. At the major national trunk road level, the EC will finance the KabulJalalabad-Torkham road in cooperation with the Swedish government. In 2002, initial support for this programme has focused on emergency and design of the full reconstruction work that will begin in 2003.

Support will also be provided for strategy and institutional capacity development in the transport sector, building on transport strategy work currently being financed by the Swedish authorities. In addition, the EC may continue urban infrastructure programmes in certain areas ( for example, building on the 2002 work with Germany), although the bulk of this support will be taken up by other donors who have decided to focus in this area.

Support in the rural feeder road network - as well as support to potable and irrigation water infrastructure - will be undertaken through the EC's support to rural recovery outlined above. A clear focus of both rural recovery and economic infrastructure programmes has been and will continue to be on labour intensive public works so as to not only rehabilitate infrastructure but also ensure a major cash injection into the economy and provide alternative jobs for day labourers currently employed in poppy production. 


\subsubsection{Pillar 3 - Trade and Investment, Public Administration and Security}

The private sector is fundamental to the future of Afghanistan, and key to future growth potential. Direct private sector support is not however an area of comparative advantage for the EC. The EC can however usefully assist in two key areas that will help to promote private sector development in Afghanistan:

- Facilitating and supporting trade. For example, assistance in understanding regulatory and market requirements and the ability to identify and exploit new market export opportunities. Advice on quality related issues such as certification and standards.

- The emergence of a micro-finance sector (but as a secondary player to the IFIs and others who have a clear comparative advantage) will include support to preliminary studies, the setting up of the legal framework taken into account the Islamic values and supporting the establishment of a micro-finance banking system.

Public administration reform is critical to improve the Government's ability to develop policy and to deliver basic services. The EC has a long tradition of support in this area and will provide support in three ways. First, the EC will through the Afghanistan Reconstruction Trust Find provide essential budget expenditures until the government revenue system is back on track. Support to the recurrent budget is considered critical to enable the ATA to finance the provision of basic services - for example in heath in education. Nonetheless, it is essential for the ATA to move to a self-financing recurrent budget as quickly as possible, support to the ARTF will therefore be linked to the ATA improving its revenue base and tackling public administration reform.

Second the EC will through contributions to the relevant Trust Funds, including LOFTA, finance programmes that enhance security and justice.

Third, the EC will support capacity building in government and help the Government tackle public administration reform (PAR). This aims to facilitate the development of a sustainable and modern public administration, which promotes gender equality. The EC is establishing capacity building groups in target ministries, especially health, ministry of public works and rural development where substantial EC resources will be directed in future. These groups will not only help directly on policy and management tasks but will most critically be the source of training for other ministry staff. This combination of functions means the essential functions of the ministries continue while the capacities of the wider group of civil servants are strengthened. As the agenda for reform of the civil service takes shape, the EC will finance measures required.

In addition, the EC is financing support to facilitate the return of qualified Afghans from the diaspora under a programme financed by a horizontal budget line of the Directorate general Justice and Home Affairs.

The holding of general elections in 2004 is the medium term objective of the Bonn Process. They will require careful preparation and massive organisational support, including a broad civic and voter education programme as these will be the first general elections in Afghanistan. The UN will without doubt play a major role in the logistical preparation of the elections. More generally, the cost associated with preparing and holding the elections should form part of the ATA's budget proposals and, as such, receive support from the ARTF. EC support to civil society could form a potential 
vehicle for helping to promote voter and civic education, taking into account the special needs of women. One possibility is an EU Observation Mission. This will be decided at a later date, following an official request by the Afghan Government and a positive recommendation from the exploratory mission. It would be funded by the EIDHR.

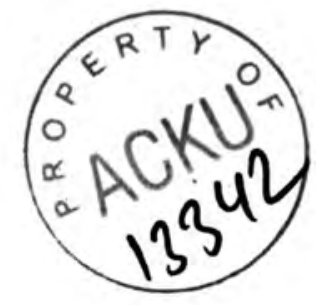

